\title{
PENDAMPINGAN PENERAPAN MODEL REALISTIC MATHEMATICS EDUCATION BERBASIS ETNOMATEMATIKA TABUT TERHADAP KEMAMPUAN LITERASI MATEMATIKA SISWA KELAS IV SDN 67 KOTA BENGKULU
}

\author{
Neza Agusdianita, V. Karjiyati, Sriken Kustianti \\ Prodi PGSD, FKIP, Unversitas Bengkulu \\ Neza.agusdianita@gmail.com
}

\begin{abstract}
This Community Service Activity aims to increase teacher knowledge about the Realistic Mathematics Education (RME) Based Ethnomatic Tabut and develop students' mathematical literacy in Elementary Schools. This activity is expected to improve teachers' skills in designing and evaluating meaningful and fun mathematics learning. The method used in this Community Service Activity is training. The instruments used in this PPM activity were observation sheets, interview sheets, and training modules. This activity data analysis is descriptive qualitative. The result of this research is that training activities for applying the Realistic Mathematics Education Model Based on Ark Ethnomatics have been carried out, which can develop students' Mathematical Literacy Ability. The community service team donated five miniature ark units and training modules to partner schools through this activity.
\end{abstract}

Keywords: RME, Ethnomathematics, Ark, Elementary Mathematics

\begin{abstract}
Abstrak
Tujuan dari Kegiatan Pengabdian Kepada Masyarakat ini adalah untuk meningkatkan pengetahuan guru tentang Penerapan Model Realistic Mathematics Education (RME) Berbasis Etnomatematika Tabut dan mengembangkan literasi matematika siswa di Sekolah Dasar. Melalui Kegiatan ini diharapkan dapat meningkatkan keterampilan guru dalam merancang melaksanakan dan mengevaluasi pembelajaran matematika yang bermakna dan menyenangkan. Metode yang digunakan pada kegiatan PPM ini adalah pelatihan. Instrumen yang digunakan dalam kegiatan PPM ini adalah lembar observasi, lembar wawancara, dan modul pelatihan. Analisis data kegiatan ini secara deskriptif kualitatif. Hasil penelitian ini ialah telah terlaksana kegiatan pelatihan penerapan Model Realistic Mathematics Education Berbasis Etnomatematika Tabut yang dapat mengembangkan Kemampuan Literasi Matematika Siswa. Melalui kegiatan ini tim pengabdi memberikan sumbangan 5 unit miniatur tabut dan modul pelatihan kepada sekolah mitra.
\end{abstract}

Kata kunci: RME, Etnomatematika, Tabut, Matematika SD

MARTABE : Jurnal Pengabdian Masyarakat 63 


\section{PENDAHULUAN}

Sekolah yang dijadikan mitra kegiatan Pengabdian Pada Masyarakat yang sedang diusulkan ini adalah SDN 67 kelurahan Surabaya kecamatan sungai serut Kota Bengkulu. Sekolah ini terletak di pinggir Kota Bengkulu yang berbatasan dengan Kabupaten Bengkulu Tengah. Prestasi sekolah ini berada pada kategori cukup, artinya prestasi yang diraih oleh sekolah ini masih sedikit. Sekolah ini juga bukanlah sekolah yang menjadi favorit para orang tua. Jarak sekolah ini sekitar enam kilometer $(\mathrm{km})$ dari kampus PGSD FKIP Unib.

Permasalahan yang dihadapi oleh guru kelas IV di sekolah tersebut dalam pembelajaran adalah bagaimana melaksanakan pembelajaran matematika yang efektif sehingga siswa dapat memahami materi pelajaran dengan baik. Siswa kelas IV di sekolah tersebut kesulitan memahami materi-materi matematika khususnya pada materi pengukuran luas dan keliling bangun datar dan volume pada bangun ruang. Guru cenderung sekarang ini memberikan rumus jadi kepada siswa tanpa melalui proses yang bagaimana rumus tersebut ditemukan.

Selain itu guru dan siswa juga kesulitan dalam memvisualisasikan konsep-konsep geometri dengan baik. Guru lebih sering menggambarkan saja di papan tulis sehingga siswa kurang baik pemahamannya tentang konsepkonsep geometri. Guru juga tidak menggunakan media pembelajaran matematika yang memudahkan siswa dalam memahami konsep. Padahal tingkat perkembangan anak usia kelas IV SD berada pada tingkat operasional konkret,artinya siswa mudah memahami suatu konsep jika mereka terlibat langsung memanipulasi bendabenda konkret. Pengalaman fisik dalam memanipulasi benda-benda konkret memiliki peranan penting bagi tahap perkembangan siswa. Karena itu, guru dituntut mampu menciptakan suasana pembelajaran yang kreatif, efektif dan menyenangkan serta melatih siswa berpikir secara sistematis dan berpikir logis.

Selain itu masalah lainnya adalah di sekolah tersebut sama sekali belum pernah melakukan pembelajaran matematika untuk mengembangkan literasi matematika siswa. Padahal literasi matematika sekarang sudah menjadi sorotan nasional. Pada data PISA tahun 2018 Indonesia menduduki peringkat 7 terendah dari 78 Negara dengan perolehan skor 379 dari 591 yang di dapat dari China dan skor 569 yang didapat dari Negara tetangga yaitu Singapura. Untuk itu dirasa perlu melakukan pelatihan dan pendampingan dalam mengukur kemampuan literasi matematik siswa di sekolah tersebut.

Berdasarkan masalah yang dipaparkan di atas, perlu dilakukan Pelatihan dan Pendampingan Penerapan Model Realistic Mathematics Education (RME) Berbasis Etnomatematika Tabut untuk mengembangkan literasi matematika bagi Siswa Kelas IV SD Negeri 67 Kota Bengkulu. Model RME ini memberikan kemudahan bagi guru dalam mengajarkan matematika. Terlebih lagi menggunakan sumber belajar dari karifan budaya lokal tabut.. Tabut sangat dekat dengan kehidupan siswa. Sehingga menambah warna dalam pembelajaran menjadi lebih menarik. Pelatihan ini dirasakan sangat penting dan berharga bagi guru dan siswa untuk memperbaiki kualitas proses dan hasil pembelajaran matematika. Untuk itu diharapkan pelatihan ini dapat dilaksanakan sesegera mungkin demi tercapainya pembelajaran tematik yang inovatif, kreatif dan menyenangkan. 


\section{METODE KEGIATAN}

Metode yang digunakan pada kegiatan PPM ini adalah pelatihan. Kegiatan pelatihan oleh tim pengabdian memberikan kesempatan bagi guru untuk dapat memahami tentang model Realistic Mathematics Education berbasis Etnomatematika Tabut. Guru dan tim dosen berdiskusi berbagi informasi mengenai hakikat pembelajaran matematika di SD, hakikat model RME, etnomatematika tabut sebagai sumber belajar kearifan lokal budaya Kota Bengkulu dan kemampuan literasi matematika siswa. Guru juga dilatih dalam membuat Rancangan pelaksanaan pembelajaran (RPP) dan media pembelajaran matematika yang sesuai dengan model pembelajaran yang digunakan.

\section{HASIL DAN PEMBAHASAN}

Kegiatan ini bertujuan untuk meningkatkan keterampilan guru di SDN 67 Kota Bengkulu agar dapat menerapkan pembelajaran matematika dengan menggunakan Model Realistic Mathematics Education Berbasis Etnomatematika Tabut. Melalui pembelajaran matematika ini diharapkan dapat mengembangkan kemampuan literasi siswa di SD tersebut. Kegatan ini dilaksanakan secara tatap muka pada tanggal 27 Agustus 2020. Kegiatan ini dilaksanakan dengan memperhatikan protokol kesehatan. Artinya dalam pelaksanaannya menggunakan masker, menjaga jarak, dilengkapi dengan sarana cuci tangan. Kegiatan ini berjalan dengan baik dan sesuai dengan yang direncanakan. Rangkaian kegiatan tersebut dimulai dari pukul 08.00 WIB. Kegiatan dimulai dengan sambutan dari Kepala Sekolah SDN 67 Kota Bengkulu yang langsung dibuka oleh kepalah sekolah. Pihak sekolah menyambut baik kegiatan ini dan memfasilitasi tempat, waktu, dan peserta untuk mengikuti kegiatan ini dengan baik. Terlihat 25 orang guru-guru di sekolah ini hadir mengikuti kegiatan ini dengan tepat waktu.

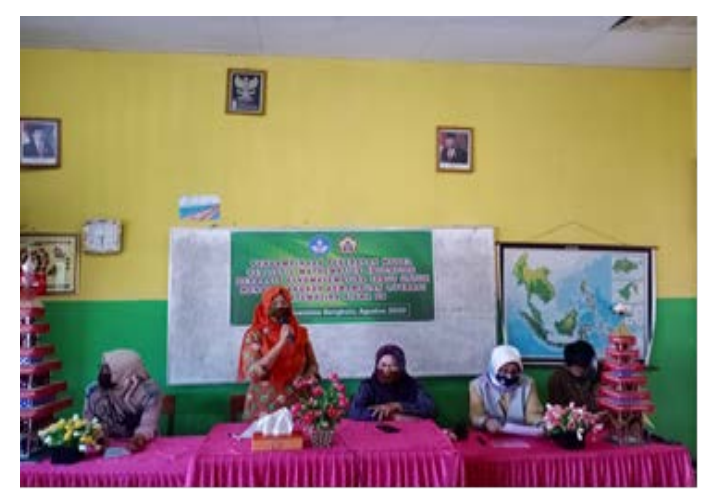

Gambar 1. Sambutan Kepala Sekolah SDN 67 Kota Bengkulu

Setelah sambutan dari Ibu Kepala Sekolah SDN 67 Kota Bengkulu dilanjutkan dengan sambutan dari tim dosen Universitas Bengkulu. Selanjutnya kegiatan dilanjutkan dengan penyampaian materi oleh tim dosen dari Unversitas Bengkulu. Ada beberapa topik materi yang disampaikan pada kegiatan pelatihan ini. Untuk topik pertama yaitu permasalahan pembelajaran matematika di SD, hakikat model pembelajaran matematika yang realistic atau Realistic Mathematic Education (RME). Materi yang pertama disampaikan oleh ibu Dra. V. Karjiyati, M.Pd yang 
merupakan dosen di Prodi PGSD Universitas Bengkulu dengan bidang keahlian Matematika SD. Berikut disajikan gambar kegiatan penyampaian materi pertama.

Topik materi selanjutnya yaitu media pembelajaran matematika, Etnomatematika Tabut merupakan kearifan lokal budaya Kota Bengkulu sebagai sumber dan media pembelajaran, pemanfaatan etnomatematika Tabut dalam pembelajaran matematika. Materi kedua ini disampaikan oleh ibu Neza Agusdianita, M.Pd yang juga merupakan dosen di Prodi PGSD Universitas Bengkulu dengan bidang keahlian matematika SD. Berikut disajikan gambar kegiatan penyampaian materi yang kedua

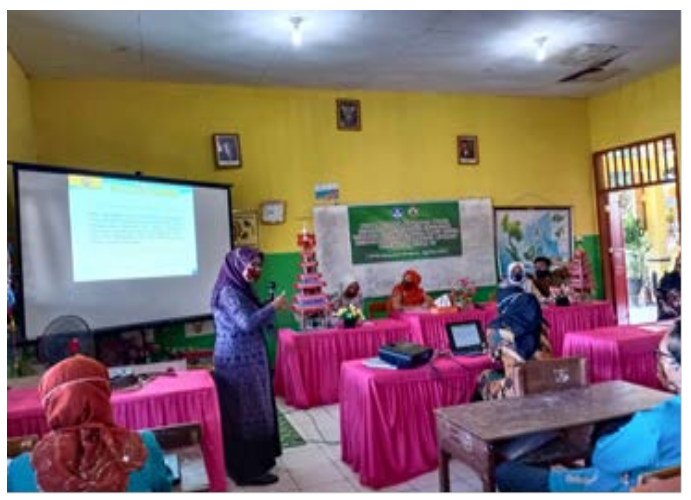

Gambar 2. Penyampaian materi model pembelajaran RME dari Ibu Dra. V. Karjiyati, M.Pd

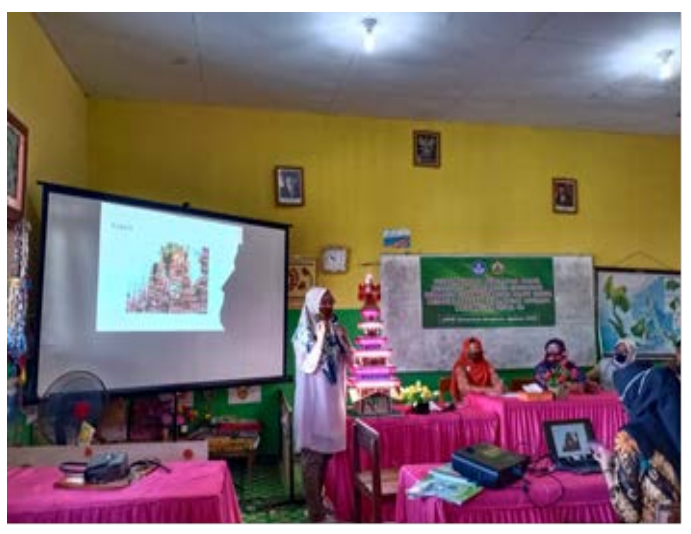

Gambar 3. Penyampaiann materi Etnomatematika Tabut dari Ibu Neza Agusdianita, M.Pd

Materi yang terakhir yaitu gerakan literasi sekolah, literasi matematika, Etnomatematika Tabut sebagai wahana mengembangkan literasi matematika.Materi ini disampaikan oleh ibu Dra. Sri Ken Kustianti, M.Pd yang merupakan dosen di Prodi PGSD Universitas Bengkulu dengan bidang keahlian strategi dan teknologi pendidikan. Penyampaian materi berlangsung dengan baik dan lancar. Berikut disajikan gambar kegiatan penyampaian materi yang ketiga.

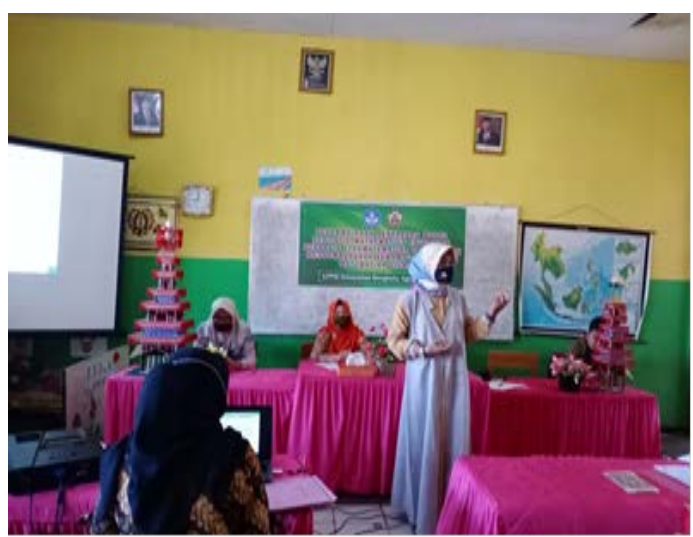

Gambar 4. Penyampaiann materi Literasi Matematika dari Ibu Dra. Sri Ken Kustianti M.Pd

Kegiatan selanjutnya yaitu diskusi langsung dengan guru-guru mengenai topik-topik yang telah dibahas sebelumnya. Guru SDN 67 Kota Bengkulu antusias bertanya mengenai kendala-kendala yang dihadapi dalam pembelajaran matematika kemudian juga berbagi pengalaman dalam praktik pembelajaran matematika yang telah dilakukannya. Terdapat juga guru yang bertanya mengenai pemanfaatan media 
Tabut dalam pembelajaran matematika di SD. Serta ada juga yang bertanya mengenai bagaimana mengembangkan literasi matematika di dalam kelas. Diskusi ini berlangsung dengan lancar. Tim dosen memberikan penjelasan mengenai permasalahan yang dihadapi oleh guru-guru di sekolah dengan baik dan mudah dipahami. Berikut disajikan gambar kegiatan diskusi antara guru dan tim dosen.

Melalui kegiatan ini tim dosen Universitas Bengkulu menyumbangkan 5 miniatur tabut kepada sekolah SDN 67 Kota Bengkulu. Miniatur tabut tersebut bisa dipakai sebagai media dan sumber belajar dalam pembelajaran matematika dan juga pembelajaran tematik. Selain itu juga tim dosen juga memberikan modul pelatihan yang berisi intisari dari materi pelatihan yang dilaksanakan agar dapat dipakai oleh pihak sekolah untuk menyegarkan informasi mengenai materi tersebut.

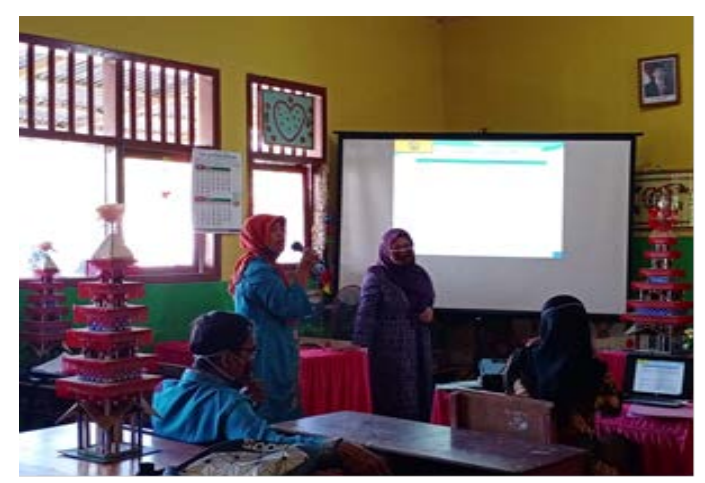

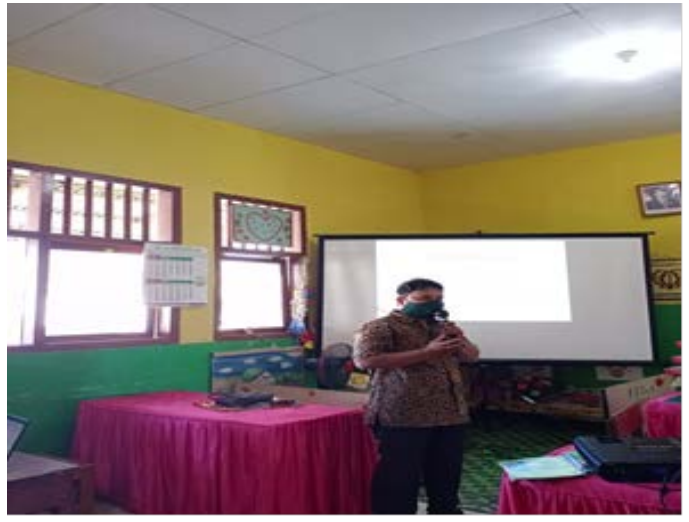

Gambar 5 dan 6. Guru dan Tim dosen berdiskusi mengenai materi pelatihan

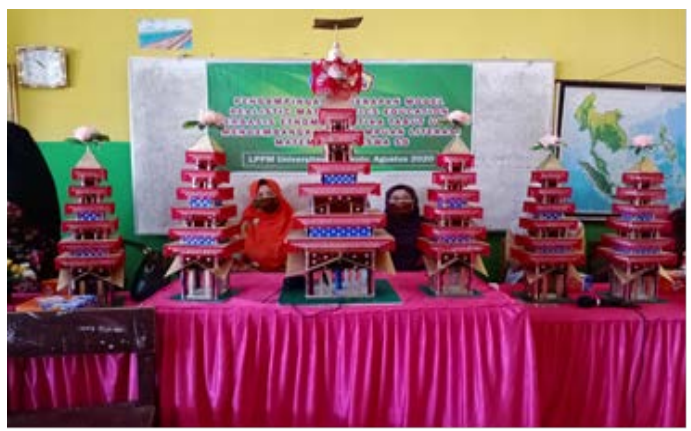

Gambar 7. Miniatur tabut yang diberikan kepada sekolah mitra

Untuk mengevaluasi keberhasilan kegiatan, tim dosen memberikan soal tes kepada guru SDN 67 Kota Bengkulu yang mengikuti pelatihan ini. Soal tes merupakan alat untuk mengukur pemahaman guru terhadap materi-materi pelatihan yang diberikan. Berdasarkan analisis data hasil tes pemahaman materi pelatihan tersebut terlihat hampir semua guru menjawab dengan benar. Rata-rata skor tes pemahaman materi pelatihan adalah 90. Data ini menunjukkan bahwa guruguru di SDN 67 Kota Bengkulu memahami dengan baik dan dapat disimpulkan kegiatan pelatihan ini berhasil dengan baik.

\section{PEMBAHASAN}

Kegiatan pengabdian ini bermaksud untuk membekali guru 
dengan pengetahuan dan keterampilan tentang penerapan model realistic mathematics education berbasis etnomatematika tabut sehingga dapat meningkatkan kemampuan literasi matematika siswa sekolah dasar. Dengan demikian guru diharapkan mampu merancang melaksanakan dan mengevaluasi pembelajaran matematika yang bermakna, aktif, inovatif, kreatif dan menyenangkan. Hal ini juga akan berdampak baik dengan prestasi belajar siswa nantinya.

Materi yang pertama disampaikan oleh ibu Dra. V. Karjiyati, M.Pd. Pada penyampaian materi ini penyaji memberikan ilustrasi-ilustrasi permasalahan pembelajaran matematika yang sering terjadi di sekolah dasar. Permasalahan pembelajaran matematika diantaranya adalah guru jarang mengikuti tahapan penyampaian materi matematika yang sesuai dengan teori belajar matematika dan teori perkembangan psikologi siswa usia SD. Guru cenderung menyampaikan materi langsung tanpa menggunakan media sebagai benda konkret. Padahal berdasarkan Teori Bruner dalam Noer (2017) menyatakan bahwa proses belajar terbagi menjadi tiga tahapan yaitu, (1) pada tahap enaktif (enactive), siswa akan mengalami peristiwa di lingkungan sekitarnya atau berhubungan dengan benda-benda real atau konkret. (2) tahap ikonik (iconic), anak mulai memahami objek-objek atau lingkungan sekitarnya melalui gambargambar dan visualisasi verbal. (3) pada tahap simbolik (symbolik), siswa telah mampu memiliki ide-ide atau gagasangagasan abstrak yang sangat dipengaruhi oleh kemampuannya dalam berbahasa dan logika. Dengan demikian guru matematika hendaknya mengajarkan materi matematika menggunakan media pembelajaran, alat peraga yang dapat memudahkan siswa untuk memahami materi pelajaran tersebut.

Penyaji juga memaparkan tentang model pembelajran realistic mathematic education (RME) yang merupakan merupakan model pembelajaran yang efektif dalam pembelajaran matematika (Agusdianita, 2020). Model ini menyajikan pembelajaran matematika secara kontekstual dan nyata disekitar siswa. Menurut Fathurrohman (2015) model RME memiliki lima karakteristik, diantaranya: 1) menggunakan masalah kontekstual, 2) menggunakan model atau jembatan dengan instrumen vertical, 3) menggunakan kontribusi siswa, 4) interaktivitas, dan 5) terintegrasi dengan topik pembelajaran lainnya. Tarigan (2006) mengemukakan suatu pendekatan RME dalam pembelajaran matematika merupakan model pendekatan mengajar dengan melibatkan persoalan-persoalan nyata dan penerapan untuk dalam sehari-hari atau bidang lain pada saat menjelaskan konsep atau pada saat menyelesaikan soal-soal

Langkah-langkah model pembelajaran realistic mathematic education (RME) menurut Soimin (2014) adapun langkah-langkah model Realistics Mathematics Education adalah. 1) Memahami masalah kontekstual, guru memberikan permasalahan berbasis masalah dan siswa diminta untuk memahami permasalahan tersebut. 2) Menyelesaikan masalah kontekstual, Siswa secara individu menyelesaikan masalah kontekstual pada lembar kerja siswa dengan caranya sendiri. Guru memotivasi siswa untuk menyelesaikan masalah tersebut dengan memberikan pertanyaan-pertanyaan penuntun untuk mengarahkan siswa dalam menyelesaikan soal. Guru diharapkan tidak memberi tahu penyelesaian soal. 
3) Membandingkan dan mendiskusikan jawaban dan 4) Menarik kesimpulan. Sedangkan menurut Fernandes (2018) tahapan model RME yaitu: 1) Guru memberikan masalah nyata; 2) Siswa mengembangkan pemikiran mereka sendiri dalam menyelesaikan masalah bentuk konkret ke abstrak; 3) Siswa diminta memberikan jawaban dan alasan; 4) Guru membimbing siswa untuk menyimpulkan belajar dan memberi tes. Pada intinya kedua pendapat tersebut sama-sama menuntut siswa untuk aktif dalam pembelajaran. Siswa diminta untuk membahas masalah-masalah yang ada dikehidupan nyata melalui konsep matematika. Tentunya dalam pembelajaran ini guru diminta untuk menyediakan media pembelajaran dan alat peraga yang sesuai dengan konsep matematika yang diajarkan.

Penyampaian materi pelatihan selanjutnya oleh Ibu Neza Agusdianita, M.Pd. Penyaji membahas mengenai etnomatematika yang bisa digunakan dalam pembelajaran matematika. Ethnomatematics adalah bentuk matematika yang dipengaruhi atau berdasarkan budaya. Shirley (1995), menyatakan bahwa saat ini bidang ethnomathematics, yaitu matematika yang muncul dan berkembang di masyarakat dan sesuai dengan budaya lokal, adalah pusat untuk belajar proses dan metode pengajaran. Ini membuka potensi pedagogis yang memperhitungkan pengetahuan siswa yang diperoleh dari belajar di luar kelas. Menurut Barton (1996), ethnomathematics termasuk ide-ide matematika, pikiran dan praktek yang dikembangkan oleh semua budaya. Ethnomathematics juga dapat dianggap sebagai program yang bertujuan untuk mempelajari bagaimana siswa memahami, mengartikulasikan, proses, dan akhirnya menggunakan matematika ide, konsep, dan praktik yang dapat memecahkan masalah yang berkaitan dengan kegiatan sehari-hari mereka. Ethnomatematics menggunakan luas konsep-konsep matematika yang berkaitan dengan berbagai matematika kegiatan, termasuk kegiatan pengelompokan, menghitung, mengukur, merancang bangunan atau alat, bermain, menentukan lokasi, dan lain-lain.

Etnomatematika merupakan matematika dalam budaya, menurut Hardiarti (2017) matematika dan budaya adalah dua hal yang saling keterkaitan, matematika dalam budaya dikenal dengan istilah etnomatematika, objek matematika yang ada di sekitar kita dapat dimanfaatkan untuk melaksanakan pembelajaran yang inovatif. Sehubungan dengan itu Auliya (2018) juga berpendapat bahwa etnomatematika adalah pembelajaran dengan unsur budaya sebagai sumber belajar untuk pembelajaran matematika, etnomatematika juga sebagai jembatan antara pendidikan dan budaya mampu memberikan pembelajaran yang lebih bermakna kepada siswa, hal tersebut dikarenakan etnomatematika mengaitkan konsep matematika dengan kebiasaan yang mereka alami dalam kesehariannya. Penyaji tertarik membahas salah salah satu kearifan lokal dari provinsi Bengkulu yaitu Tabut sebagai etnomatematika.

$$
\text { Menurut Dahri }
$$

mengatakan bahwa kata Tabut berasal dari bahasa Arab "At-Tabutu" yang berarti peti yang terbuat dari kayu. Selain itu, Dahri juga mengemukakan tabut yang terdapat di Kota Bengkulu merupakan sebuah bangunan yang menyerupai pagoda atau menara yang bertigkat-tingkat terbuat dari rangka kayu dan bambu, pada bangunan terkadang ditambahi hiasan. Sehubungan dengan itu Giyarto (2010) 
juga mengungkapkan bahwa upacara Tabut merupakan ritual tradisional masyarakat Bengkulu, upacara ini diadakan untuk mengenang kisah kepahlawanan cucu Nabi Muhammad saw., yaitu Huseein bin Ali bin Abi Thalib yang wafat dalam peperangan di Padang Karbala, Irak. Festival Tabut merupakan agenda besar di Provinsi Bengkulu yang selalu diramaikan oleh masyarakat. Festival tabut menghadirkan semua bangunan tabut dari berbagai keluarga tabut. Festival Tabut ini sangat ditunggu-tunggu oleh semua kalangan mulai dari anak usia SD sampai dengan orang dewasa.

Matematika dapat digali melalui etnomatematika ini sehingga Tabut dapat digunakan sebagai media dan sumber belajar pada pembelajaran matematika. Pada bangunan tabut yang bertingkat-tingkat terdapat banyak muatan matematika yaitu unsur-unsur bangun datar, unsur-unsur bangun ruang, jenis-jenis bangun datar dan bangun ruang, pengukuran panjang, pengukuran luas, pengukuran keliling, pengukuran volume, kesebangunan dan pola. Etnomatematika Tabut ini sesuai untuk dipadukan dengan model pembelajaran RME karena keduanya berangkat dari kontekstual siswa. Etnomatematika Tabut bisa mewarnai mulai dari tahapan awal dalam model pembelajaran model RME. Guru bisa menyajikan masalah yang dikaitkan dengan festival tabut dan bangunan tabut itu sendiri. Berikut disajikan gambar miniature tabut yang digunakan dalam kegiatan pelatihan ini

Penyaji yang ketiga adalah ibu Dra. Sri Ken Kustianti, M.Pd. Pada kesempatan ini penyaji membahas tentang literasi. Gerakan literasi sekolah merupakan suatu keharusan. Literasi karena skor literasi Indonesia yang menduduki peringkat bawah di dunia. Literasi yang dibahas penyaji lebih fokus kepada literasi matematika. wahyudin dalam Abidin dkk (2018), literasi matematis yaitu kemampuan untuk mengeksplorasi, menduga dan bernalar secara logis serta menggunakan berbagai metode matematis secara efektif untuk menyelesaikan masalah. Sementara menurut Kusumah dalam Abidin dkk (2018) literasi matematis adalah kemampuan menyusun serangkaian pertanyaan, merumuskan, memecahkan dan menafsirkan permasalahan. Sehingga disimpulkan literasi matematika adalah kemampuan yang dimiliki oleh siswa untuk dapat memecahkan masalah matematika melalui kegiatan mengamati objek, memahami masalah menyelesaikan masalah.

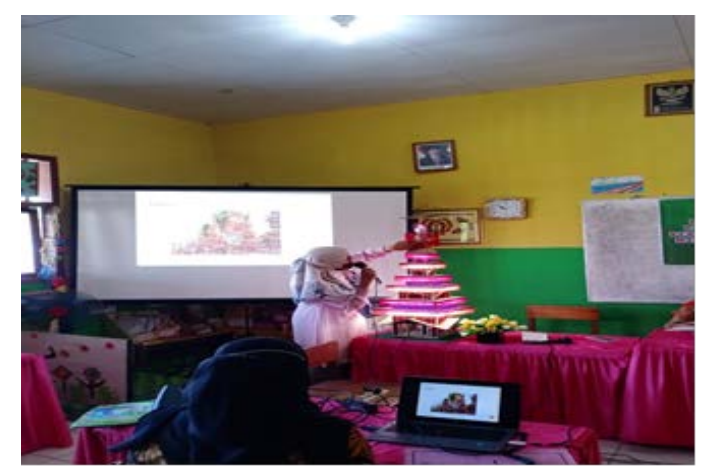

Gambar 8. Penyaji membahas konsep matematika yang ada pada etnomatematika Tabut

Literasi matematika memiliki komponen-komponen. Dalam PISA 2018 terdapat tiga komponen literasi matematis yaitu komponen proses, komponen konten matematika dan komponen konteks matematika. Komponen proses mendeskripsikan bagaimana siswa menjelaskan prosedur dalam memecahkan masalah. Komponen konten mendeskripsikan pemahaman siswa tentang konsep matematika dalam memecahkan masalah. Sedangkan komponen konteks mendeskripsikan kemampuan siswa memecahkan masalah melalui konteksual atau masalah nyata. Literasi matematika ini bisa dikembangkan 
salah satunya dengan etnomatematika Tabut. Sehingga siswa bisa melihat tabut dengan kacamata literasi matematika misalnya berapa kertas yang habis terpakai untuk menutupi permukaan bangunan tabut, bangun ruang apa saja yang ada dalam bangunan tabut dan lainnya.

Berdasarkan penjelasan di atas dapat disimpulkan bahwa model pembelajaran realistic mathematic education (RME) berbasis etnomatematika Tabut merupakan salah satu alternatif dalam mewujudkan pembelajaran matematika yang efektif, inovatif dan bermakna. Selain itu juga dapat dijadikan wahana untuk mengembangkan kemampuan literasi matematika siswa SD.

\section{KESIMPULAN}

Berdasarkan hasil pelaksanaan kegiatan pengabdian kepada masyarakat yang telah dilaksanakan di SDN 67 Kota Bengkulu, maka dapat disimpulkan hal-hal sebagai berikut:

1. Telah terlaksana kegiatan pelatihan model pembelajaran realistic mathematic education (RME) berbasis etnomatematika Tabut untuk mengembangkan kemampuan literasi siswa SD pada tanggal 27 Agustus 2020. Kegiatan berlangsung dengan baik dan lancar sesuai dengan yang direncanakan.

2. Guru-guru di SDN 67 Kota Bengkulu telah memahami materi pelatihan dengan baik.

3. Tim dosen memberikan 5 buah miniature Tabut dan modul pelatihan yang berisi intisari dari materi pelatihan.

\section{UCAPAN TERIMA KASIH}

Tim dosen kegiatan pengabdian kepada masyarakat mengucapkan terima kasih kepada pihak lembaga penelitian danpengabdian kepada masyarakat yang telah memfasilitasi dana untuk kegiatan ini.

\section{DAFTAR PUSTAKA}

Abidin, dkk., (2018),Pembelajaran Literasi: Strategi Meningkatkan Kemampuan Literasi Matematika, Sains, Membaca, dan Menulis, Jakarta: Bumi Aksara

Agusdianita, Neza, Salati Asmahasanah, Penyusunan Perangkat Model Quantum Teaching Dalam Pembelajaran Matematika Menggunakan Rme Untuk Meningkatkan Prestasi Belajar, Kreativitas, Dan Karakter Siswa Sd, Attadib Journal Of Elementary Education, Vol. 4 (1), Juni 2020

Auliya, N. N. F. (2018). Etnomatematika Kaligrafi Sebagai Sumber Belajar Matematika Di Madrasah Ibtidaiyah. Jurnal Pendidikan Matematika, 1(2), 78-98.

B. Barton, "Making Sence of Etnomatematic Etnomatematic is Making Sence," Educ. Stud. Mat.,vol. 3, no. 1, pp. 201-233, 1996

Dahri, H., (2009), TABOT; Jejak Cinta Keluarga Nabi di Bengkulu, Bengkulu: Penerbit Citra.

Fathurrohman, M., (2015), ModelModel Pembelajaran Inovatif Alternatif Desain Pembelajaran yang Menyenangkan, Jogjakarta: $\quad$ AR-RUZZ MEDIA.

Fernandes, M. (2018), Enhancement Results Learning Troubleshooting Using Realistic Mathematics 
Education Approach In Elementary School. Vol. 1 No. 1 (83-90)

Giyarto, (2010), Pesona Wisata Bengkulu, Klaten: PT Macanan Jaya Cemerlang

Hardiarti, S. (2017). Etnomatematika: Aplikasi Bangun Datar Segiempat Pada Candi Muaro Jambi. Aksioma, 8(2), 99. https://doi.org/10.26877/aks.v8 i2.1707
L. Shirley, Using Ethnomatematics to find Multicultural Matematical Connection. NTCM, 1995

Noer, S.H., (2017), Strategi Pembelajaran Matematika. Yogyakarta: Matematika.

Shoimin, Aris. (2014). Model Pembelajaran Inovatif Dalam Kurikulum 2013. Yokyakarta: AR-ruz media

Tarigan, Daiti. 2006. Pembelajaran Matematika Realistik. Dikti. Jakarta. 